\title{
Review of Binding Agents in Syntactic Foams for Heat-Insulating Structures in Power Industry Facilities
}

\author{
Artem Vyacheslavovich Ryzhenkov ${ }^{1}$, Natalia Aramovna Loginova ${ }^{1}$, Elena Vladimirovna Belyaeva ${ }^{1}$, Yevgenij \\ Yevgenjevich Lapin ${ }^{1} \&$ Andrey Fedorovich Prischepov ${ }^{1}$ \\ ${ }^{1}$ National Research University "Moscow Power Engineering Institute", Krasnokazarmennaya str., 14, Moscow, \\ 111250, Russia \\ Correspondence: Natalia Aramovna Loginova, National Research University, Moscow Power Engineering \\ Institute, Moscow, Russia. E-mail: natalja.log@yandex.ru
}

Received: October 30, 2014

Accepted: November 10, $2014 \quad$ Online Published: December 14, 2014

doi:10.5539/mas.v9n4p96

URL: http://dx.doi.org/10.5539/mas.v9n4p96

\begin{abstract}
The article deals with heat-insulating coatings used in power industry. Special attention is paid to syntactic foams manufactured with the use of microspheres and various binding agents. Raw materials used in syntactic foams are analysed. Use of microspheres in syntactic foam structures defines their heat-insulating properties, ensures material density and heat conductivity reduction, whereas binding agents ensure mechanical strength and thermal stability of heat-insulating coating.
\end{abstract}

Keywords: heat insulation, structures, heat-insulating materials, syntactic foams, microspheres, composite materials, heat conductivity, mechanical strength

\section{Introduction}

The modern heat-insulating materials (HM) market offers a wide range of heat-insulating coatings created with the use of various binding agents and microspheres, so called syntactic foams. Syntactic foams are a type of gas-filled composite polymer materials (PCM), where the filling agents are hollow spherical particles evenly distributed in the binding agent. Cells in such foams are formed not as a result of polymer foaming, but due to introduction of hollow microspheres (Dodiuk \& GoodmanJohn, 2013). Microsphere presence makes the material a close-grained one.

Syntactic foams producers propose to use them both for heat insulation of guarding structures of buildings and for protection of industrial facilities operated at temperatures of up to $600^{\circ} \mathrm{C}$, e.g. pipelines and power equipment. At the same time there are publications with very negative assessment of this type of heat-insulating coatings (Korelshtein, 2011). The basis for criticism is ads of a number of producers where they state that the heat conductivity factor $(\mathrm{HCF})$ is $\sim 0.001 \mathrm{~W} /(\mathrm{m} \cdot \mathrm{K})$, and recommending to form a heat-insulating layer e.g. on the pipeline surface of the heating system with the heat medium temperature of $\sim 150^{\circ} \mathrm{C}$ of just $1 \div 2 \mathrm{~mm}$. The key reason for such contradictions is little knowledge about syntactic foam properties as regards high temperature facilities, lack of their classification.

The quantity and quality of introduced microspheres impact the heat-insulating properties of the material; herewith there are associated affects present: increase in viscosity and appearance or growth in system strength (Li et al., 2011; Loginova, 2010; Liao et al., 2011). A majority of filled systems studied demonstrate the critical filling level, above which there is a sharp change in rheological parameters and strength values (Varlamova et al., 2011).

Introduction of microspheres and other filling agents into polymers is accompanied by formation of a new set of composite properties. This process is a result of interphase interactions at the polymer-solid phase interface, including, first of all, absorption or molecular interactions responsible for adhesion at the interface, physical, mechanical and other properties of filled systems (Zavyalova et al., 2007). The critical issue is optimal polymer/filling agent composition. The mechanical properties of filled composites may change depending on the filling particles shape. One should take into account not only the nature, shape and distribution pattern of the filling particles, but also their interaction at the phases interface (Katz \& Milewski, 1987).

In turn, binding agents included into syntactic foams ensure mechanical strength and thermal stability of the 
heat-insulating material, and when a base metal is used on the surface - additional anticorrosion protection (Loginova, 2010; Deepthi et al., 2010; Wang et al., 2012).

The objective of this review is identification of the most perspective binding agents for syntactic foams designed to be used in heat-insulating structures of power equipment and pipelines.

Patent information, guidance manuals and scientific periodicals were analysed and summed up during the article preparation.

\section{Patent Information Analysis}

Table 1 contains the patents describing HM, where filling agents are microspheres (Varlamova et al., 2011; Motrikale, 2008; Belyaev, 2005; Belyaev, 2007; Telegin et al., 2002; Amirova et al., 2011; Bessonov et al., 2012; Grinavtsev et al., 2013; Epifanovskiy et al., 1995; Osnovin, 2003; Markin et al., 2006; Gavrikov et al., 2004).

The most commonly used binding agents for syntactic foams are those based on organic polymers: acrylic latex and epoxy resins, polyurethane foam because they are characterized by high adhesion both to metal and microsphere material (Dodiuk \& GoodmanJohn, 2013). In order to increase the end material efficiency, PCMs are supplemented with various additives: plasticizing agents, fire-retarding agents, dispersing agents, stabilizing agents, and pigments.

Table 1. Patents describing heat-insulating materials with the use of microspheres

\begin{tabular}{|c|c|c|c|}
\hline Filling agents & Binding agent & Other additives & $\begin{array}{l}\text { Functionality, max. operating } \\
\text { temperature }\end{array}$ \\
\hline $\begin{array}{l}\text { Air-filled ceramic } \\
\text { and silicone, } \\
\text { carbon white; } \\
\text { aerogel; } \\
\text { expanded } \\
\text { vermiculite; } \\
\text { expanded perlite }\end{array}$ & Acrylic latex. & $\begin{array}{l}\text { Antifoaming agent } \\
\text { Sotro-145; } \\
\text { Conserving agent; } \\
\text { Pigment; } \\
\text { Dispersing agent; } \\
\text { Densifier; } \\
\text { Water; Water-repelling agent }\end{array}$ & $\begin{array}{l}\text { Heat insulation and } \\
\text { waterproofing, noise } \\
\text { suppression, anticorrosion } \\
\text { protection, fire-resistance, } \\
\text { durability. Coating heat } \\
\text { resistance is } 600-650^{\circ} \mathrm{C} \text {, heat } \\
\text { conductivity factor is } 0.001 \\
\mathrm{~W} / \mathrm{m} \times \mathrm{K}\end{array}$ \\
\hline $\begin{array}{l}\text { Modified ash } \\
\text { microspheres }\end{array}$ & Polyurethane & - & $\begin{array}{l}\text { Increased material durability as } \\
\text { compared to non-modified } \\
\text { microspheres, } 2-7 \text {-fold moisture } \\
\text { absorption reduction. }\end{array}$ \\
\hline $\begin{array}{l}\text { Glass, ceramic, } \\
\text { polymer, ash and } \\
\text { their mixes (size: } \\
10-500 \mu \mathrm{m} \text { ) }\end{array}$ & $\begin{array}{l}\text { Latex composite: } \\
\text { acrylate homopolymer, } \\
\text { styrene acrylate } \\
\text { copolymer; } \\
\text { butadiene-styrene } \\
\text { copolymer, polystyrol, } \\
\text { butadiene polymer, } \\
\text { PVC polymer, } \\
\text { polyurethane polymer, } \\
\text { vinyl acetate polymer or } \\
\text { copolymer }\end{array}$ & $\begin{array}{l}\text { Water, surface active agents } \\
\text { (OP-6, OP-7, OP-10, } \\
\text { praxanols), pigments } \\
\text { (titanium dioxide/ zinc } \\
\text { oxide), fireproof additives } \\
\text { (aluminium trihydrate, } \\
\text { ammonium polyphosphate, } \\
\text { zinc borate, mica, asbestos), } \\
\text { rust solvent PRL-2, } \\
\text { corrosion inhibitors (sodium } \\
\text { nitrate, sodium benzoate, } \\
\text { guanidine chromate, zinc } \\
\text { tetraoxychromate, AKOR-1, } \\
\text { NG-203) }\end{array}$ & $\begin{array}{l}\text { Heat resistance up to } 150^{\circ} \mathrm{C} \text {. } \\
\text { Increased anticorrosion and } \\
\text { heat-insulating protection }\end{array}$ \\
\hline $\begin{array}{l}\text { Glass and/or } \\
\text { polymer }\end{array}$ & Epoxy binding agent & $\begin{array}{l}\text { Hardening agents of amine } \\
\text { and amide type groups }\end{array}$ & High adhesion to a pipe \\
\hline $\begin{array}{l}\text { Glass } \\
\text { microspheres }\end{array}$ & Epoxy resin & $\begin{array}{l}\text { Glycidyl ether of phosphorus } \\
\text { acids; hardening agent }\end{array}$ & $\begin{array}{l}\text { Heat conductivity factor is } \\
0.02-0.03 \mathrm{~W} / \mathrm{m} \times \mathrm{K}\end{array}$ \\
\hline $\begin{array}{l}\text { Aluminium } \\
\text { silicate }\end{array}$ & $\begin{array}{l}\text { Sodium and/or } \\
\text { potassium liquid glass }\end{array}$ & - & $\begin{array}{l}\text { It is characterized with the } \\
\text { compression density of up to } \\
11 \mathrm{MPa} \text { and heat conductivity } \\
\text { factor of } 0.16-0.175 \mathrm{~W} / \mathrm{m} \times \mathrm{K}\end{array}$ \\
\hline
\end{tabular}




\begin{tabular}{|c|c|c|c|}
\hline $\begin{array}{l}\text { A mix of } \\
\text { metalized and } \\
\text { non-metalized } \\
\text { ceramic } \\
\text { microsheres }\end{array}$ & $\begin{array}{l}\text { Styrene acrylic latex, } \\
\text { sodium liquid glass, } \\
\text { low-molecular silicone } \\
\text { rubber }\end{array}$ & - & $\begin{array}{l}\text { Increased protection against } \\
\text { heat and electromagnetic } \\
\text { radiation. }\end{array}$ \\
\hline $\begin{array}{l}\text { Glass } \\
\text { microspheres }\end{array}$ & $\begin{array}{l}\text { Polyorganosilica } \\
\text { block-polymer Lestosil } \\
\text { SM (TOR } \\
\text { 38.03.1.006-90) and } \\
\text { low-molecular silicone } \\
\text { rubber SK TNF (TOR } \\
\text { 38-103129-77). }\end{array}$ & Boron nitride & Fireproof coating \\
\hline $\begin{array}{l}\text { Ceramic and } \\
\text { silicone } \\
\text { microspheres }\end{array}$ & $\begin{array}{l}\text { A mix of } \\
\text { butadiene-sterol rubber } \\
\text { and acrylic polymer }\end{array}$ & $\begin{array}{l}\text { Carbonic microfibers, } \\
\text { pigment (titanium oxide, } \\
\text { lead chrome), water }\end{array}$ & $\begin{array}{l}\text { Increased adhesion, breaking } \\
\text { strength of } 2.4 \mathrm{kgf} / \mathrm{mm}^{2} \text {, heat } \\
\text { conductivity: } 0.029-0.034 \\
\mathrm{~W} / \mathrm{m} \times \mathrm{K}\end{array}$ \\
\hline Ash microspheres & Polyurethane & - & $\begin{array}{l}\text { Density of } 51 \mathrm{~kg} / \mathrm{mm}^{3} \text {, } \\
\text { compressive strength of } 1.36 \\
\mathrm{MPa} \text {, heat conductivity factor: } \\
0.124 \mathrm{~W} / \mathrm{m} \times \mathrm{K}\end{array}$ \\
\hline $\begin{array}{l}\text { Glass } \\
\text { microspheres }\end{array}$ & Polyurethane & - & $\begin{array}{l}\text { Compressive strength up to } \\
0.95 \mathrm{MPa} \text {. reduction in the } \\
\text { material burning behaviour as } \\
\text { compared to foamed } \\
\text { polyurethane. Density: } \\
51-75 \mathrm{~kg} / \mathrm{m}^{3}\end{array}$ \\
\hline
\end{tabular}

\section{Binding Components. Thermoplastic and Thermosetting Materials}

The main task during HMs production is the binding material selection. The key characteristics of the formed composite material, such as operating temperatures range, impact resistance, water resistance and weatherability, chemical resistance depend primarily on the matrix type. Binding components may be organic, hetero-organic and non-organic polymers. In terms of the technological processing, organic and hetero-organic polymers may be divided into two large categories - thermoplastic and thermosetting.

Thermoplastic materials processing is based on their ability to become elastic when heated to the temperature above the transformation temperature, and where the temperature is above the flow point and melting point into the plastic state, and to set when cooled to the temperature below the transformation temperature and melting point. The advantage of thermoplastic materials is their processability, high impact strength, crack resistance, and durability (Mascia, 1989). Such binding materials include polyolefins, polyethyleneterephthalate, aliphatic polyamides, polyformaldehyde, polyimides and many others. But thermoplastic materials have disadvantages as well, the main of them being low thermal stability (Margolis, 1985).

As compared to thermoplastic materials, thermosetting binding materials have wider possibility for regulating the viscosity, wetting and saturating abilities. Articles made of thermosetting materials are characterized by high mechanical strength and heat resistance, but in terms of impact ductility and crack resistance they are worse than thermoplastic materials. Thermosetting binding materials are characterized by grid structure formation as a result of reactive oligomers or low-molecular monomers polymerization. Recently the method for polymers production using reactive oligomers has been widely used. The typical materials obtained under such a method are epoxy resins, polyesteracrylates and polyurethanes. Polymer material properties are greatly dependant on functional classification (functional groups) of their oligomer raw material (Entelis et al., 1989). The most sensitive the physical and chemical properties are to presence of multifunctional oligomers in reactive oligomers which lead to defects in the special grid polymer structure. E.g. polyurethanes: the higher the multifunctional oligomer fraction is, the lower the modulus of elasticity, breaking strength and special grid density are (Entelis et al., 1989).

Perspective binding materials for heat-insulating coatings are polymer matrixes used for PCMs production (Harris, 1999). We have systematized the key classes of organic and non-organic polymers according to the 
chemical composition of their elementary unit (Table 2) (Lubin, 1982).

Table 2. Forming material characteristics

Binding material classes
Thermosetting binding materials
Glyphtal resins
R-II $-\mathrm{O}-\left[\mathrm{CH}_{2}-\mathrm{CH}-\mathrm{CH}_{2}-\mathrm{O}-I_{\mathrm{OH}}\right.$

Oligoester maleates<smiles>CCCOC(=O)C=CC(=O)OCCC(C)(C)O</smiles>

Resol phenol-formaldehyde resins

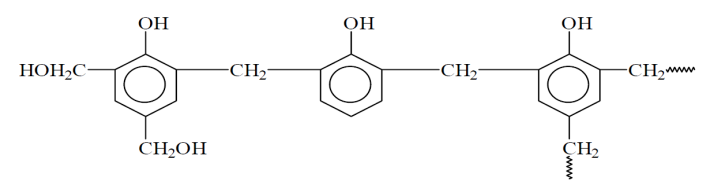

Bulk phenol-formaldehyde resins

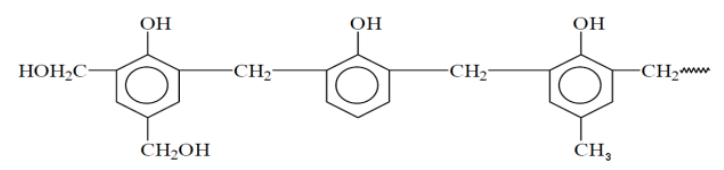

Urethane resins (polyurethanes (PU)) based on the following urethane group:<smiles>CNC(=O)OC</smiles>

Epoxy resins containing at least two epoxy groups in the molecule:

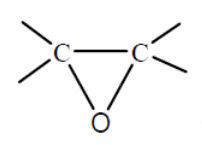

Organosilicone binding materials
Main forming material characteristics

Slow setting, at room temperature accompanied by considerable material contraction and brittle coatings formation. Resulting coatings possess anticorrosive properties, good weatherability and heat resistance up to $150^{\circ} \mathrm{C}$.

Setting at room temperature. Good adhesion to glass fibre, paper and metals. Minimal coating compaction at setting. Coatings resistant up to $80-100^{\circ} \mathrm{C}$.

Setting at heating to $170-180^{\circ} \mathrm{C}$ with formation of solid polymers resistant to water, solvents and acids save for sulphuric and nitric acids. Stable at heating up to $200-250^{\circ} \mathrm{C}$.

Characterized by linear molecular structure. Setting at $150-200^{\circ} \mathrm{C}$ in the presence of hexamethylenalnine (6-14\%). Highly water resistant. Gradual destruction at the temperatures above $280^{\circ} \mathrm{C}$.

Setting at room temperature within 30-150 minutes. Insoluble in water and conventional solvents. Characterized by good adhesion to the following materials: fabric, paper, wood, glass, plaster, and metals. Ageing resistance is several times higher than that of artificial and natural resins. The main disadvantage: combustibility and emissions toxicity. Operating temperatures range: $-50^{\circ} \mathrm{C}$ to $+130^{\circ} \mathrm{C}$.

Possible setting at room temperature using catalytic agents and increased temperatures $\left(170-220^{\circ} \mathrm{C}\right.$ within 40-20 minutes). Coatings are characterized by good water and chemical resistance. Heat resistance depends on the chemical grid structure which depends on the setting agent and lies in the range of $150-320^{\circ} \mathrm{C}$. Resulting coatings are brittle.

Thermal and catalytic setting. Coatings are characterized by water-repellent properties, increased heat resistance, 
<smiles>[R][Si]([R])(OC(C)(C)C)C(C)(C)C</smiles>

Polyimide and bismaleimide binding materials

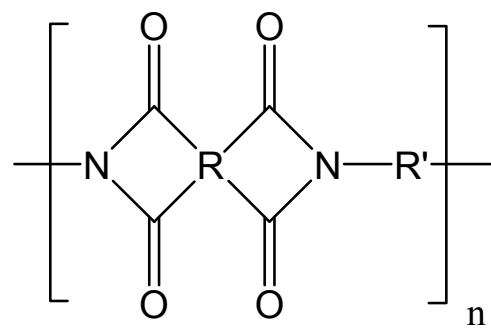

Thermoplastic binding materials

Polyolefins

1. Polyethylene

2. Polypropylene

3. Polystyrol

Polyethyleneterephthalate (PET)<smiles>CCC(C)(O)CCOC(=O)c1ccc(C(=O)OC2([14CH3])CC2)cc1</smiles>

Aliphatic polyamides, contain an amide group in the main polymer chain:

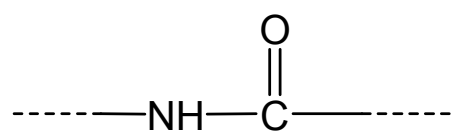

Polyacrylates resistance to ozone and aggressive media. Used as anticorrosion agents. Elasticity, hardness and durability of silicone resins, depends on the degree of monomer cross-linkage. At low temperatures, coatings preserve their elasticity and are resistance to ageing. Properties remain constant up to $370^{\circ} \mathrm{C}$.

Both thermal $\left(300-350^{\circ} \mathrm{C}\right.$ in inert atmosphere) and chemical polymerization. Coatings have grid matrix with increased mechanical durability and heat resistance. Depending on the interaction type between main chains, they may belong to thermoplast materials chacaterized by increased stability up to $280^{\circ} \mathrm{C}$, and short-term stability up to $400^{\circ} \mathrm{C}$.

Polyethylene elasticity depends on its density and reduces as the density increases, and the polymer hardness grows. Polypropylene has the best bending resistance as compared to other thermoplastic materials.

Polypropylene and polyethylene are resistant to water, water vapour, organic solvents, mineral acids and alkali.

Styrol is a good dielectric; it is characterized by low heat-conductivity and is brittle. It is resistant to organic solvents, concentrated alkali and acid solutions.

Polyolefins-based materials can be operated at the temperatures up to $140^{\circ} \mathrm{C}$.

The operating temperature range is up to $170^{\circ} \mathrm{C}$. PET fibres are very durable, elastic and chemically stable. PET films do not conduct water vapour, oxygen, nitrogen and solvent vapours.

Highly solid, durable and wear resistant. Operating temperatures range: up to $215^{\circ} \mathrm{C}$.

Soluble in their own monomers, compound ethers, aromatic hydrocarbons and chlorohydrocarbons. Lower polyacrylates are soluble in acetone and not soluble in non-polar solvents. Softening temperatures range of polyacrylates based on aliphatic dicarboxylic acids: 
<smiles>[R]OC(=O)C([R])(C)C(C)(C)C(C)(C)C</smiles>

Fluoroplastics<smiles>CC(C)(C)C(F)(F)C(F)(F)F</smiles>

Aromatic polyamides<smiles>CCC(=O)c1cccc(C(=O)Nc2cccc(NC(C)(C)C)c2)c1</smiles>

Polysulfones

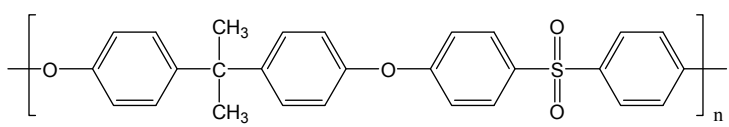

Polyester-ketones (PEK)

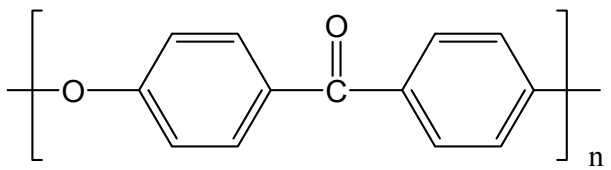

Polyphenylene sulfide (PPS)

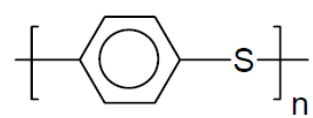

$30-240^{\circ} \mathrm{C}$, and those based on aromatic dicarboxylic acids: $120-350^{\circ} \mathrm{C}$. Air decomposition temperature is $300-350^{\circ} \mathrm{C}$.

Temperature range for various fluoroplastics grades formation is $150-327^{\circ} \mathrm{C}$. Fluoroplastics are characterized by high electric strength, low friction coefficient, resistance to aggressive media, weatherability, corrosion and radiation resistance, weak gas permeability, non-combustibility, non-solubility in the majority of organic solvents and water.

One of most rigid-rod synthetic polymers. Softening temperatures range: $300-400^{\circ} \mathrm{C}$. Solubility and heat resistance of aromatic polyamides depend on submicroscopic structure of the polymer being formed. Polymers belonging to this class are widely used for highly durable organic fibres production.

Resistant to radiation, chemically stable to alkali solutions, lean mineral acid solutions, lean and saturated solutions of mineral salts, aliphatic hydrocarbons, motor oils and diesel fuels, petroleum oils, surface active agents. Processed at $300-380^{\circ} \mathrm{C}$.

Most widely used in industries is polyester-ester-ketone (PEEK) with the melting point of $340-390^{\circ} \mathrm{C}$. Characterized by high heat and fire resistance, resistance to UV light, hot water and vapour.

Characterized by increased hardness and shock resistance, dimension stability at continuous load, exceptional chemical stability, including stability to motor and aviation fuel. Low degree of water absorption (below $0.02 \%$ ). Dielectric. Coatings may be continuously operated at $60-220^{\circ} \mathrm{C}$ and can withstand short-term heating to $270^{\circ} \mathrm{C}$.

Recently hybrid matrixes combining thermoplastic and thermosetting components have been actively developed making it possible to benefit from the advantages of the two main binding materials classes. Composite materials based on the describe polymers (see Table 1) are used practically in any industry: power engineering, aviation, space exploration, automobile manufacturing, shipbuilding, construction, household appliances manufacture, medicine.

Table 1 shows that the thermal stability of organic and elementorganic polymers does not exceed $400^{\circ} \mathrm{C}$. However supplementation with special additives results in increase in thermal stability of organic polymers. For instance, silicone resins by Dow Corning modified with such non-organic pigments as aluminium paste and 
metal oxides may be used in high-temperature media, up to $760^{\circ} \mathrm{C}$ (Presentation Dow Corning, 2014).

\section{Non-Organic Binding Agents}

Besides organic binding materials, where one of the disadvantages is their high cost, syntactic foams are produced using non-organic binding agents (Bessonov et al., 2012). In the mentioned patent, liquid glass is used for ash microspheres binding. Use of non-organic compounds as the matrix has some advantages: availability, low cost, possibility of using the composite material at high temperatures.

Let's discuss the main class of mineral (non-organic) construction binding compounds which include agents capable of passing from liquid or doughlike state into solid state under the influence of internal physical and chemical processes, and binding other components. In terms of their setting method, binding materials used in construction are divided into air and hydraulic binding materials (see Table 3). Air binding materials can set and preserve their durability for a long time only in the air, while in damp conditions they soak and quickly lose their durability (e.g. air-setting lime, gypsum, clays) (Volzhenskiy et al., 1979).

Table 3. Construction binding materials

\begin{tabular}{ll}
\hline Non-organic binding agents & Setting method \\
\hline Lime (based on $\left.\mathrm{Ca}(\mathrm{OH})_{2}\right)$ & \\
Clays $\left(\mathrm{Al}_{2} \mathrm{O}_{3}\right.$ and $\left.\mathrm{SiO}_{2}\right)$ & Air \\
Gupsum $\left(\mathrm{CaSO}_{4} \cdot 0,5 \mathrm{H}_{2} \mathrm{O}\right.$ or $\left.\mathrm{CaSO} \mathrm{O}_{4}\right)$ & \\
Magnesian $($ main component: $\mathrm{MgO})$ & \\
Liquid glass $\left(\mathrm{Na}_{2} \mathrm{O}\left(\mathrm{SiO}_{2}\right)_{\mathrm{n}}\right.$ and $/$ or $\left.\mathrm{K}_{2} \mathrm{O}\left(\mathrm{SiO}_{2}\right)_{\mathrm{n}}\right)$ & \\
Gypsum-cement-pozzolanic binding agent: & \\
$50-75 \%$ gypsum plaster, $15-25 \%$ portland cement, $10-20 \%$ active mineral & \\
admixtures & In air and humid environment \\
$\mathrm{Systems} \mathrm{comprising} \mathrm{four} \mathrm{oxide} \mathrm{compounds:}$ & \\
$\mathrm{CaO}-\mathrm{SiO}_{2}-\mathrm{Al}_{2} \mathrm{O}_{3}-\mathrm{Fe}_{2} \mathrm{O}_{3}$, they also include ettringite binding agents & \\
$\left(m \mathrm{CaO} \cdot n \mathrm{Al}_{2} \mathrm{O}_{3}, \mathrm{CaSO}_{4}\right)$ & \\
\hline
\end{tabular}

In systems comprising four oxide compounds (Table 2), depending on one oxide domination, there are Roman cement, silicate cements (including Portland cement), alumina cements (aluminous cement), and ettringite binding agents (expanding and non-shrinking cements) (Odler, 2003). The key distinctive feature of non-organic binding materials is loss of plastic and viscous characteristics upon setting, that is, formation of a structure with molecular bonds. The plasticizing agent added to cement is clay due to its high plasticity and the ability to retain water on the surface of its finely dispersed particles.

During the recent decade, the number of papers on use of glass hollow and aluminosilicate microspheres in masonry mortar is actively growing. In the article (Kumar, 2003; Kumar, 2000) justify use of hollow microspheres in order to reduce cement stone density and heat conductivity and to lighten masonry mortars. E.g. (Rozovskaya and Semenov, 2013) describes development of construction admixtures composition on the basis of hollow aluminosilicate and glass microspheres. It was found out that the optimal density $\left(\leq 600 \mathrm{~kg} / \mathrm{m}^{3}\right)$ and the heat conductivity factor $(0.16 \mathrm{~W} /(\mathrm{m} \times \mathrm{K}))$ are achieved if glass microspheres are used as the filling material. The authors of (Kirillov and Semenov, 2009) managed to obtain a cement masonry mortar with the dry density of $400 \mathrm{~kg} / \mathrm{m}^{3}$ where glass microspheres content is up to 50\%. In Inozemtsev and Korolev (2013), a complex nanosize modifying agent was developed in order to increase cement-and-mineral matrix adhesion durability with the use of glass microspheres. The proposed modifying agent makes it possible to structure concrete admixture, to increase cohesion at the matrix-microspheres interphase boundary, and to increase the system viscosity, thus ensuring even special filling material distribution. Materials described in the mentioned papers are used in construction.

Currently there is a growing need for effective modern high-temperature heat-insulating materials (Suvorov, 2002). For high-temperature objects, phosphate binding agents are used (in engineering they are cold "binding substances"). Such compounds belong to concentrated water solutions of non-organic polymers included into non-organic glues (Sychev, 1986). In terms of the typical binding substances mortars there are two groups: 1) mortars on the basis of alkaline silicates and aluminum silicates, 2) phosphate mortars. The Russian market offers a wide range of fireproof glues, based both on phosphate bounds (AFS, ABFK, AHFS) and aluminum silicates (KOZ-Z, NS-Sh, NS-1). Non-organic glues have a number of advantages: they are non-toxix, fire and explosion proof and possess acid resistant and protective features; and the operating temperatures range is up to 
$2,000^{\circ} \mathrm{C}$. In order to make glues or glue-based articles capable of being operated under high temperatures, the binding substance is supplemented with additional fire-proof filling agents, such as $\mathrm{SiO}_{2}, \mathrm{Al}_{2} \mathrm{O}_{3}, \mathrm{Fe}_{2} \mathrm{O}_{3}$ with the particle size of $1 \mu \mathrm{m}$ (Sychev, 1986).

The authors of (Danilova et al., 1980) obtained the raw admixture for heat-insulating materials including a phosphate binding agent, alumina-containing component and phosphate microspheres as a filling agent. The operating temperature of the resulting composition was $1,200^{\circ} \mathrm{C}$. Aluminium-chromium-phosphate binding (ACPB) agent is used as a film-forming component. Thus, patent (Makhlay et al., 2011) describes fire-proof ACPB-based composition, OSA-1 hardening agent and glass microspheres. This composition possesses improved technological properties, in particular ability to swell under high temperatures.

Heat-resistant phosphate material with the variable density was obtained in (Pak et al., 2010). Heat-resistant materials with variable density are obtained due to layer-wise filling agents introduction; filling agents used were coal clay, used calalytic agent IM-2201 and aluminosilicate microspheres. The peculiarity of this composition is its spontaneous setting during isothermal synthesis due to aluminium powder introduction.

Use of phosphate and aluminosilicate binding substances for heat-insulating microsphere-based materials has not been studied to the sufficient extent. At the same time, it is obvious that they are perspective for use in composite materials in order to extend the operating temperatures range of heat-insulating materials. Therefore their further study is of importance.

\section{Discussion}

Specialists are of the opinion that practically all modern traditional heat-insulating materials are apt to quick ageing and destruction; their actual operating life is maximum ten years (Ivanov et al., 2010). So there is an objective need to search for and use new heat-insulating materials, one of which is syntactic foams. It is reasonable to claim that soon syntactic foams will be in great demand and will be competitive at the heat-insulating market.

\section{Conclusion}

Use of microspheres in syntactic foams influences their heat-insulating properties, reduces material density and heat conductivity.

Binding substances included into syntactic foams ensure mechanical strength and thermal stability of heat-insulating coating. The advantage of thermoplastic agents use as binding materials is their processability, high impact resistance, crack resistance, and durability. The constraint for use in heat-insulating structures for pipelines and power equipment is relatively low thermal stability $\left(\sim 20{ }^{\circ} \mathrm{C}\right)$. Thermosetting binding materials are characterized by high mechanical durability and thermal stability, but they are worse in terms of impact viscosity and crack resistance. Thermal stability of organic and elementorganic polymers is max. $400^{\circ} \mathrm{C}$. But supplementation with special additives results in considerable increase in thermal stability of organic polymers. High thermal stability (up to $2,000^{\circ} \mathrm{C}$ ) of phosphate and aluminosilicate binding substances makes them very perspective for use in heat-insulating structures for pipelines and power equipment, but need further study.

\section{Acknowledgement}

The work was undertaken with the financial aid by the Ministry of Education and Science of the Russian Federation under Agreement No.14.574.21.0022 dated June 17, 2014 "Development of composite heat-insulating materials for thermal power equipment encasing using autonomous mobile high-duty units" (unique identification number RFMEFI57414X0022).

\section{References}

Amirova, L. M., Andrianova, K. A., Rybakov, V. V., Ovchinnikov, E. V., \& Amirova, L. R. (2011). The method for heat-insulating gradient coating: patent RU 2424905 C1; application: 2009143210/05, 23.11.2009; published 27.07.2011, Bull. 21.

Belyaev, V. S. (2005). Anticorrosion and heat-insulating coating based on hollow microspheres: patent RU 2251563 C2; application: 2003112108/04, 24.04.2003; published 10.05.2005 Bull. 13.

Belyaev, V. S. (2007). Use of composites filled with hollow microspheres as an anticorrosion and heat-insulating pipeline coating: patent RU 2304600 C2; application: 2005123302/04, 22.07.2005; published 20.08.2007, Bull. 23.

Bessonov, I. V., Sepelin, A. N., \& Kordyukov, N. P. (2012). The method for construction heat-insulating material 
based on aluminosilicate microspheres: patent RU $2455253 \mathrm{C} 1$; application: 2011107564/03, 01.03.2011; published 10.07.2012, Bull. 19.

Danilova, T. A., Duderov, Y. G., \& Fekhretdinov, F. A. (1980). Raw mix for heat-insulating articles production: patent RU 753824; application: 2652330/29-33, 03.08.1987; published 07.08.1980.

Deepthi, M. V., Sharma, M., Sailaja, R. R. N., Anantha, P., Sampathkumaran, P., \& Seetharamu, S. (2010). Mechanical and thermal characteristics of high density polyethylene-fly ash Cenospheres composites. Materials and Design, 31, 2051-2060. http://dx.doi.org/10.1016/j.matdes.2009.10.014.

Dodiuk, H., \& GoodmanJohn, S. (2013). Handbook of Thermoset Plastics (3rd ed.). San Diego, SD: William Andrew. http://dx.doi.org/10.1016/B978-1-4557-3107-7.00013-0.

Entelis, S. G., Evreinov, V. V., \& Kuzaev, I. A. (1989). New concepts in polymer science. Great Britain, GB^ The Alden Press Ltd.

Epifanovskiy, I. S., Dimitrienko, Y. I., Polezhaev, Y. V., Medved, Y. V., \& Mikhatuliy, D. S. (1995). The method for fire-resistant coating: patent RU 2039070; application: 93027483/05, 18.05.1993; published 09.07.1995.

Gavrikov, Yu. M., Masik, I. V., Sirotinkin, N. V., \& Yatsenko, S. V. (2004). Heat-insulating composition based on solid polyurethane: patent RU 2226202; application: 2001124895/04, 31.08.2001; published 27.03.2004.

Grinavtsev, V. N., Grinavtsev, O. V., \& Chernogil, V. B. (2013). Heat-insulating coating: patent RU 2473751 C1; application: 2011128144/03, 07.07.2011; published 27.01.2013, Bull. 3.

Harris, B. (1999). Engineering Composite Materials. Great Britain, GB: IOM.

Inozemtsev, A. S., \& Korolev, E. V. (2013). Hollow microspheres: effective filling agent for highly durable light concrete. Industrial and civil construction, 10, 80-83.

Ivanov, V. V., Bukarov, N. V., \& Vasilenko, V. V. (2010). Impact of insulation and ground moistening over heat losses in subsurface heat traces. Electronic magazine. Energosovet, 7(12).

Katz, H. S., \& Milewski, J. V. (1987) Handbook of fillers and reinforcements for plastics. New York: Van Nostrand Reinhold Co.

Kirillov, K. I., \& Semenov, V. S. (2009). Superlight mason solutions. MSU Bulletin, 3, 106-112.

Korelshtein, L. (2011). Liquid thermal insulation: false efficiency. CADmaster, 3, 14-16.

Kumar, S. (2000). Fly ash-lime- phosphogypsum cementitious binder: A new trend in bricks. Materials and Structure, 33(1), 59-64. http://dx.doi.org/10.1007/bf02481697

Kumar, S. (2003). Fly ash-lime-phosphogypsum hollow blocks for walls and partitions. Build. Environ, 38(2), 291-295. http://dx.doi.org/10.1016/S0360-1323(02)00068-9

Li, B., Yuana, Y., An, Z., \& Zhang, J. (2011). Effect of microstructure and physical parameters of hollow glass microsphere on insulation performance. Material Letters, 65(12), 1992-1994. http://dx.doi.org/10.1016/j.matlet.2011.03.062

Liao, Y., Wua, X., Liua, H., \& Chen, Y. (2011) Thermal conductivity of powder silica hollow spheres. Thermochimica Acta, 526, 178-184. http://dx.doi.org/10.1016/j.tca.2011.09.011

Loginova, N. A. (2010) Determination of thin-film thermal insulation coatings efficiency in heat supply systems. (Master's theses, National Research University "Moscow Power Engineering Institute", Moscow).

Lubin, G. (1982). Handbook of composites. New York, NY: Van Nostrand Reinhold Company.

Makhlay, V. N., Afanasiev, S. V., Roschenko, O. S., \& Kuzmin, I. V. (2011). Fire retardant composition for metal structures: patent RU 2422489 C1; application: 2009142903/05, 19.11.2009; published 27.06.2011 Bull. 18.

Margolis, G. M. (1985). Engineering Thermoplastics: Properties and Applications. New York, NY: CRC Press.

Markin, V. B., Ananieva, E. S., \& Krjukov, A. S. (2006). Heat-insulating composition: patent RU 2279414 C1; application: 2005102256/04, 31.01.2005; published 10.07.2006, Bull. 19.

Mascia, L. (1989). Thermoplastics: Materials Engineering. Oakland, O: Elsevier Applied Science.

Motrikale, N. V. (2008). Liquid ceramic insulating coating: patent RU 2342415 C1; application: 2007125899/04, 10.07.2007; published 27.12.2008, Bull. 36 .

Odler, I. (2003). Special Inorganic Cements. New York, NY: CRC Press.

Osnovin, E. V. (2003). Liquid heat-insulating coating: patent RU 2206550; application: 2001115852/03, 
14.06.2001; published 20.06.2003.

Pak, Ch. G., Abyzov, V. A., \& Batrashov, V. M. (2010). Heat-resistant phosphate cellular materials with variable density. SUSU Bulletin. Construction and Architecture, 15, 4-5.

Presentation: Dow Corning. Resins and intermediates. Selecrion Guide. In Rishichem Distributors Pvt. Retrieved August 4, 2014, from http://www.rishichem.com/uploads/products/docs/file_15.pdf

Rozovskaya, T. A., \& Semenov, V. S. (2013). Properties of the Dry Masonry Mixtures with Hollow Ceramics $\begin{array}{lllll}\text { Microspheres. } \quad \text { Advanced } & \text { Materials } & \text { Research, 860-863, } & \text { 1244-1247. }\end{array}$ http://dx.doi.org/10.4028/www.scientific.net/amr.860-863.1244

Suvorov, S. A. (2002). Modern problems during fire-resistant materials production for metallurgic industry. New refractory materials, 3, 38-45.

Sychev, M. M. (1986). Non-organic glues. St. Petersburg, St. P.: Chemistry.

Telegin, V. A., Telegina, E. B., Gorev, V. A., Shestakov, S. P., Remizov, V. V., Mikhailov, N. V., Timonin, V. I., \& Gaziyants, A. P. (2002). The method for heat-insulating material based on syntactic foam, heat-insulated pipe and the method for heat-insulating coating application to the external pipe surface: patent RU 2187433; application: 99121870/12, 21.10.1999; published 20.08.2002.

Varlamova, L. P., Varykhin, V. A., Domrachev, G. A., Drozhzhin, V. S., Egorov, V. A., Izvozchikova, V. A., ... Semenov, N. M. (2011). Heat-insulating composition: patent RU 2414495 C1; application: 2009125209/05, 01.07.2009; published 20.03.2011, Bull. 8.

Volzhenskiy, A. V., Burov, Yu., \& Kolokolnikov, V. S. (1979). Mineral binding agents: technology and properties. Moscow, M.: Stroyizdat.

Wang, C., Liu, J., Du, H., \& Guo, A. (2012). Effect of fly ash cenospheres on the microstructure and properties of silica-based composites. Ceramics International, 38, 4395-4400. http://dx.doi.org/10.1016/j.ceramint.2012.01.044

Zavyalova, N. B., Stroganov, V. F., Stroganov, I. V., \& Akhmetshin, A. S. (2007). A study of the filling agents impact over durability characteristics of heterophase polymet compositions. Izvestiya KGASU, 1(7), 63-66.

\section{Copyrights}

Copyright for this article is retained by the author(s), with first publication rights granted to the journal.

This is an open-access article distributed under the terms and conditions of the Creative Commons Attribution license (http://creativecommons.org/licenses/by/3.0/). 